\title{
ENERGY AUDIT OF A TEXTILE MILL - A CASE STUDY
}

\author{
Muhammad ABID \\ Interdisciplinary Research Center, COMSATS Institute of Information Technology, \\ Wah Cantt, Pakistan. \\ drabid@ciitwah.edu.pk \\ (Received: 18 May. 2015; Accepted: 14 Dec. 2015; Published on-line: 30 Apr. 2016)
}

\begin{abstract}
The textile industry plays a pivotal role in Pakistan's economy. The industry's share for overall manufacturing activity is $46 \%$; in the export sector it is $68 \%$; in value addition it is $9 \%$ of GDP and in providing employment it is $38 \%$, in addition to the foreign exchange earnings, investment and contribution to the value added industry. In spite of this major contribution, the textile industry is at a severe risk due to hefty increases in energy costs. Keeping in view of these challenges in order to technically support the textile industry, energy audit of a textile mill ihas been carried out and areas of energy wastage are identified with an estimated cost saving of almost Rs. 6.8 million. Finally recommendations are given for cost effective measures for efficient energy usage, estimation of implementation costs and payback periods.
\end{abstract}

ABSTRAK: Industri tekstil mempunyai peranan yang penting dalam ekonomi Pakistan. Saham industri tekstil untuk aktiviti pembuatan keseluruhan adalah $46 \%$; eksport adalah $68 \%$; nilai tambah adalah $9 \%$ daripada KDNK dan penyediaan pekerjaan adalah $38 \%$, sebagai tambahan kepada pendapatan tukaran asing, pelaburan dan sumbangan kepada industri nilai tambah. Walaupun sumbangan besar ini , industri tekstil adalah atas risiko yang teruk disebabkan oleh peningkatan besar dalam kos tenaga. Tetap melihat cabarancabaran ini bagi menyokong industri tekstil teknikal, audit tenaga kilang tekstil dijalankan dan bidang pembaziran tenaga dikenal pasti dan penjimatan kos yang dianggarkan hampir Rs. 6.8 juta selesai. Akhir sekali cadangan yang diberikan adalah untuk langkah yang berkesan kos untuk penggunaan tenaga yang cekap, penganggaran kos pelaksanaan dan tempoh bayar balik.

KEYWORDS: Energy; Audit; Loss; Consumption; Economy

\section{INTRODUCTION}

In any industry, the three major operating costs include energy (electrical and thermal), labor and materials. Among these, the cost of energy is rated at the top [1-4]. Considering the current power crisis in Pakistan; the importance of the energy management function increases manifold. Energy audit provides a bench-mark and basis for more effective planning for the use of energy in any organization [5-11]. Textile industry is the major role player for country's economy [12-17]. In Pakistan, textile industry shares for overall manufacturing activity is $46 \%$; export is $68 \%$; value addition is $9 \%$ of GDP and employment provision is $38 \%$, in addition to the foreign exchange earnings, investment and contribution to the value added industry [18-21] . In this paper energy audit of a textile industry in Pakistan is presented. Areas of energy losses are identified; suggestions for cost effective measures to establish efficient energy use and estimation of implementation costs and payback periods are calculated and discussed. Process layout of a textile mill is shown in 
Fig. 1. Different types of cotton are mixed in mixing section; fibres made are sent to blow room to clean, blend, remove micro dusts and to provide uniform feed to the carding machine; which separates and cleans cotton fibers for spinning. In spinning, yarn is made from cotton fibers by drawing out and twisting into a thin strand. Finally, cloth made is wound on the rolls for the required lengths.

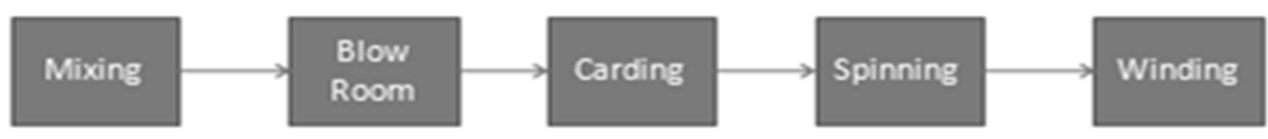

Fig. 1: Textile industry layout.

For energy audit, a survey was conducted regarding energy distribution, energy consumption, energy conversion and energy management system in the above mentioned sections of a textile mill $[4,15,16,18]$. Based on the survey, four energy resources i.e. gas, diesel oil, LESCO (electricity from Lahore electric supply company) used in the textile mill are identified.

\section{DATA ANALYSIS AND DISCUSSION}

From detailed survey and analysis, it was observed that 4 gas engines each of capacity of $1 \mathrm{MW}$ used in the textile mill provide $80 \%$ of the energy needs with $64 \%$ of the total bill of the textile mill; therefore, these engines are focused to determine potential energy savings. The highest cost of energy was observed of LESCO; hence gas is recommended to be used mostly. Percentage distribution of cost and energy per year is shown in Fig. 2.

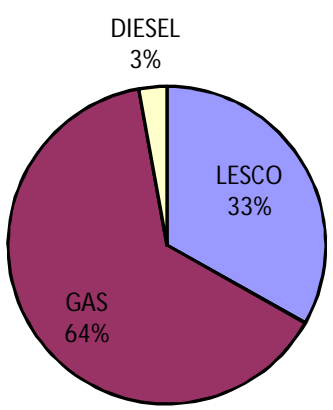

(a)

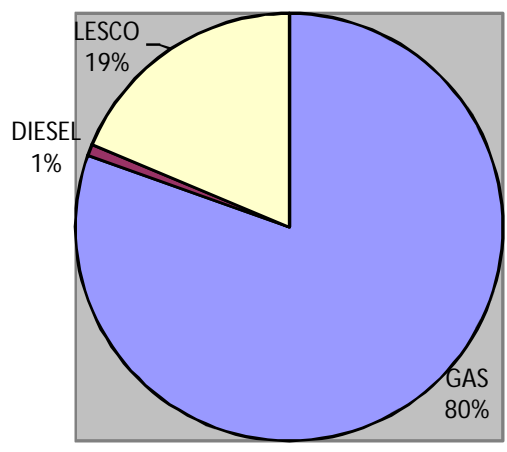

(b)

Fig. 2: Percentage distribution per year: (a) cost, (b) energy.

During production, loads on the engines are distributed to provide necessary energy for the industry and average consumption of each engine is adjusted according to each engine's efficiency. The engine with the highest efficiency is recommended to be used for the maximum power generation, and vice versa. This leads to the reduction of annual gas consumption and will translate into savings in monetary terms. Average annual efficiency of $33.3,34.1,33.9,34.3$ is calculated for gas engines 1, 2, 3, 4 respectively. Hence, in this case engine 4 should be used more and engine 1 should be used least.

Regarding load distribution, maximum consumptions is observed in the months of February and March because higher temperature is needed to be maintained as the 
temperatures outside is observed less (Fig. 3a). In addition, the maximum energy consumption is observed in the spinning units $1 \& 2$ (Fig. 3b).

Power quality analyzer was used to measure output power of each equipment in the respective department [4]. Based on the total load distribution across each department, line losses from the input and the output were determined for Spin 1 and 2 of $4.84 \%$ and in Spin 3 of $2.12 \%$. Spin 1 and 2 is old and Spin 3 is the new mill, therefore percentage loss of the new mill is observed comparatively less than the old mill. A constant loss of $174.11 \mathrm{~kW}$ is calculated based on input and output of different sections and equipment used for Spin 1 and 2 and monthly percentage of energy consumption (gas, diesel and LSCO), corresponding rates of energy sources, and cost of the monthly and yearly losses is summarized in Table 1.

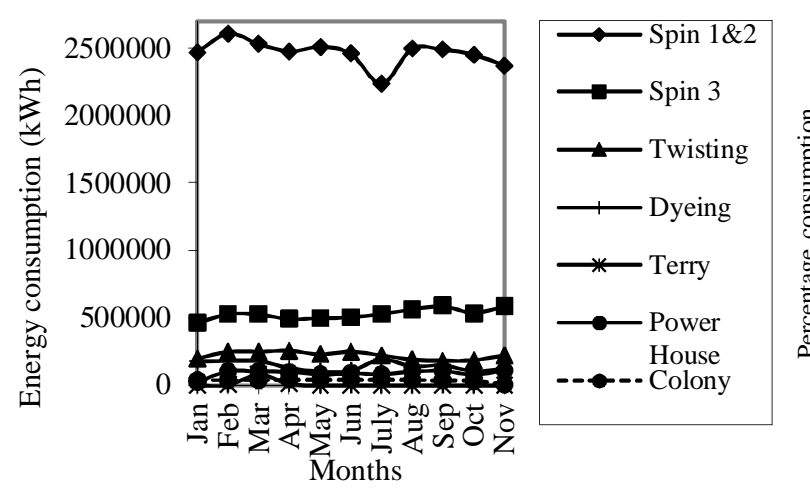

(a)

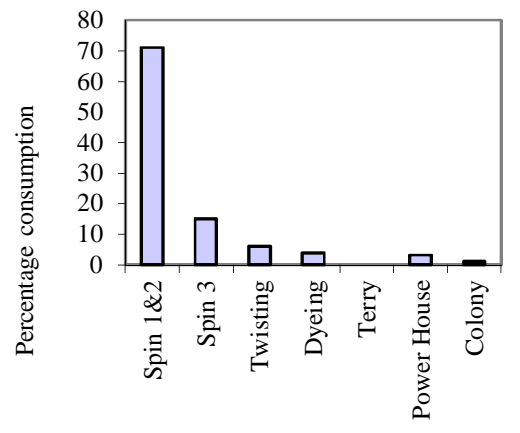

Textile mill sections

(b)

Fig. 3: Monthly load distribution for departments; (a) energy (kWh), (b) percentage.

\section{SOURCES OF MAJOR ENERGY LOSSES FROM EQUIPMENT}

In order to determine sources of energy losses during consumption, data was collected from the major equipment i.e. compressors, capacitors, motors, and fans and are discussed below in detail $[4,15,16,18]$.

Compressors are an essential part of a textile industry and are used to run the different pneumatic machinery, movement of cotton in the ducts and for cleaning purposes. Five screw type compressors used in the textile mill were analyzed and a total energy loss of 15 $\mathrm{kW}$ with equivalent energy loss of $10800 \mathrm{kWh}$ per month was calculated.

Mainly three types of motors are used in a textile mills. 4 motors of rated power $15 \mathrm{~kW}$ are used for cooling water, 4 motors of rated power $5.5 \mathrm{~kW}$ are used for cooling tower and 7 motors of $7.5 \mathrm{~kW}$ are used for engine exhaust fans. For these motors total energy loss calculated is $2.55 \mathrm{~kW}$ and total energy loss per month calculated is $1836 \mathrm{kWh}$.

Power factor and power losses for each capacitor due to unnecessary high power consumption by the capacitors were calculated $[15,16,18]$. A benchmark value of $1.2 \mathrm{~kW}$ power recommended for the best conditioned capacitors based on the energy audit of several textile mills was used. Power losses were calculated by subtracting the total power consumed by a capacitor bank from the bench mark value of $1.2 \mathrm{~kW}$. All three phase ccapacitors of frequency $50 \mathrm{~Hz}$ each were analysed in different sections i.e. LT-1 (Qty = 12), LT-2 (Qty = 12), LT-3 (Qty = 8), LT-4 (Qty = 16, 12 were operational), LT-Dying (Qty = 
10, 6 were operational). Energy loss of 2.81, 3.59, 2.7, 2.0, 2.7 were observed in LT-1, LT2, LT-3, LT-4, and LT-dying respectively and total energy loss calculated was $13.8 \mathrm{~kW}$. Total losses per day and per annum calculated were $331.2 \mathrm{kWh} /$ day and $120,888 \mathrm{kWh} /$ year respectively.

Table 1: Total loss for one year for Spin $1 \& 2$

\begin{tabular}{|c|c|c|c|c|c|c|c|c|}
\hline \multirow[t]{2}{*}{ Month } & \multicolumn{3}{|c|}{$\begin{array}{c}\text { Percentage } \\
\text { Consumption }\end{array}$} & \multicolumn{3}{|c|}{ Cost (Rs/kWh) } & \multirow{2}{*}{$\begin{array}{c}\text { Monthly } \\
\text { Losses }\end{array}$} & \multirow{2}{*}{$\begin{array}{c}\begin{array}{c}\text { Monthly } \\
\text { Losses }\end{array} \\
(\text { Rs })\end{array}$} \\
\hline & Gas & Diesel & LESCO & Gas & Diesel & LESCO & & \\
\hline Oct & 83.46 & 1.33 & 15.21 & 3.42 & 15.30 & 3.56 & 125359 & 451170 \\
\hline Nov & 91.93 & 0.33 & 7.73 & 3.38 & 13.70 & 3.54 & 125359 & 429586 \\
\hline Dec & 69.26 & 0.00 & 30.74 & 3.36 & 0.00 & 3.62 & 125359 & 431225 \\
\hline Jan & 26.07 & 5.23 & 68.70 & 3.35 & 14.23 & 3.85 & 125359 & 534342 \\
\hline Feb & 86.80 & 2.90 & 10.30 & 3.44 & 12.51 & 3.58 & 125359 & 466011 \\
\hline Mar & 91.38 & 0.07 & 8.54 & 3.46 & 9.62 & 3.58 & 125359 & 435581 \\
\hline Apr & 89.16 & 0.27 & 10.58 & 3.48 & 12.28 & 3.60 & 125359 & 440768 \\
\hline May & 73.74 & 0.26 & 26.00 & 3.54 & 11.30 & 2.81 & 125359 & 422489 \\
\hline Jun & 87.01 & 0.29 & 12.69 & 3.60 & 8.35 & 3.60 & 125359 & 453028 \\
\hline July & 73.91 & 0.43 & 25.66 & 3.61 & 17.33 & 3.68 & 125359 & 462161 \\
\hline Aug & 88.39 & 0.60 & 11.01 & 3.44 & 7.31 & 3.62 & 125359 & 436635 \\
\hline \multirow[t]{2}{*}{ Sep } & 97.08 & 0.11 & 2.81 & 3.32 & 11.50 & 3.55 & 125359 & 418133 \\
\hline & & & & & \multicolumn{3}{|c|}{ Total Yearly Losses in Rs } & 5381133 \\
\hline
\end{tabular}

Air conditioning for maintaining a certain temperature and humidity level plays an important role in a textile mill $[15,16,18]$. The fiber requires humidity to get their strength and require supply of warm humid air. This is where the role of supply fans comes into play. Then there is also the need for the recirculation of the warm air as induction of fresh air in every cycle would mean a high load on the heating coils. Also the suspended cotton fibers in the air cause irritation if swallowed, thus a mechanism is required to throw them out of the system. This is what return fans are used for. They suck the air from the process room along with these suspended fibers and other particles and circulate them through a filter and back to the supply fans and into the process room. The use of fans on a scale of significant magnitude meant that they formed a substantial part of the total load of the textile mill and thus required special attention during audit. Results of total power consumed and percentage power savings are summarized in Table 2. Discharge or flow rate of each fan was calculated using averaged air velocity and area of the fan. Total discharge or flow rate for a particular process room was calculated by adding the flow rates of all fans. Specific power consumption was calculated by dividing the flow rate of each fan to the power consumed by that fan. The highest value of specific power consumption for a fan in a particular process room was set as a standard. Total power consumed at maximum specific power of all the fans of a particular process room was calculated by dividing the total discharge or flow rate by the maximum specific power consumption. 
Table 2: Supply and return fans savings

\begin{tabular}{|c|c|c|c|c|c|c|}
\hline $\begin{array}{l}\text { Fan } \\
\text { Type }\end{array}$ & Department & $\begin{array}{c}\text { Total Power } \\
\text { Consumed } \\
\text { at maximum } \\
\text { Specific Power }(\mathrm{kW})\end{array}$ & $\begin{array}{l}\text { Total Actual } \\
\text { Power } \\
\text { Consumption } \\
\quad(\mathrm{kW})\end{array}$ & $\begin{array}{l}\text { Power } \\
\text { Saving } \\
\text { per kW }\end{array}$ & $\begin{array}{c}\text { Power } \\
\text { Saving/Year } \\
(\mathrm{kWh})\end{array}$ & $\begin{array}{l}\text { Saving } \\
\text { \%age }\end{array}$ \\
\hline \multirow{2}{*}{$\begin{array}{l}\text { Supply } \\
\text { Fans }\end{array}$} & $\begin{array}{l}\text { Blow, Card } \\
\text { Room }\end{array}$ & 10.19 & 25.33 & 15.14 & 132626 & $60 \%$ \\
\hline & Ring $1 \& 2$ & 46.03 & 96.03 & 50 & 438000 & $52 \%$ \\
\hline \multirow[t]{2}{*}{$\begin{array}{l}\text { Return } \\
\text { Fans }\end{array}$} & $\begin{array}{l}\text { Blow, Card } \\
\text { Room, } \\
\text { Drawing, } \\
\text { Simplex, } \\
\text { Comber }\end{array}$ & 19.73 & 24.78 & 5.05 & 44238 & $20 \%$ \\
\hline & Ring $1 \& 2$ & 64.76 & 84.72 & 19.96 & 174850 & $24 \%$ \\
\hline
\end{tabular}

\section{ENERGY LOSS CALCULATIONS}

Finally, monthly energy losses of all equipment of a textile mill calculated are summarized in Table 3 [12-15].

Losses for the month $=($ gas percent consumption $\times$ monthly loss $\times$ monthly gas rate $)+$ (diesel percent consumption $\times$ monthly loss $\times$ monthly diesel rate) $+($ LESCO percent consumption $\times$ monthly loss $\times$ LESCO rate $)$

\section{RECOMMENDATIONS}

Regular inspections to identify the faulty capacitors should be done and written logs for maintenance schedule history should be maintained. In compressors, use of cool air intake, flows rate regulation as per requirement, highest volumetric efficiency, air compression to lower pressure level to reduce loading and unloading time for lesser power input, proper covering of exhausts should be ensured. For fans, belt inspection, motor and fan replacement as required after identification, bearing lubrications and predictive maintenance of fans must be ensured. Use of proper capacity and number of electric motors, better quality windings, anti-scaling agents for water softening for smooth operation of pumps and $\mathrm{HCl}$ for cleaning the nozzles for eliminating the pressure losses and hence to reduce the power input be ensured. In addition regular and timely checkup of alignment, belts and bearings is strongly recommended. Replacement of tungsten bulbs with fluorescent lamps and reduction of number of lamps by local lighting compared to the global lighting results in considerable cost savings. For steam transportation over long distances, high pressure and small diameter of pipes is desired, with pressure reducing valves placed as necessary to regulate the steam pressure at the point of use, thereby curbing heat losses. Pressure losses around bends are great; it is desirable to make their radii large. To prevent steam leaks from joints due to the thermal expansion of the pipe, expansion joints should be placed where required. To maintain the temperature inside the valve, tank and treatment tank as well as the piping, it is necessary to install them heat-insulated, using appropriate heat insulating materials, so as to efficiently use steam while preventing heat losses. A constant check of housekeeping must be made from time to time and proper masks to workers for their health safety should be provided. 
Table 3: Monthly data: percent consumption, energy loss and financial loss

\begin{tabular}{|c|c|c|c|c|c|c|c|c|c|c|c|c|c|c|c|c|c|c|c|c|}
\hline & & & & & $\mathrm{t} / \mathrm{kV}$ & & & $\begin{array}{l}\text { otal } \\
\text { Ene }\end{array}$ & $\begin{array}{l}\text { Con } \\
\text { rgy }\end{array}$ & tant & $\begin{array}{l}\text { Mor } \\
(\mathbf{k W}\end{array}$ & $\begin{array}{l}\text { athly } \\
\text { h) }\end{array}$ & & & Iontl & $\begin{array}{r}\text { ly } F \\
(P\end{array}$ & $\begin{array}{l}\text { nanc } \\
\text { ak Rs }\end{array}$ & $\begin{array}{l}\text { ial L } \\
\text { s) }\end{array}$ & osse & \\
\hline 䒿 & שี & 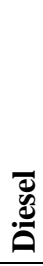 & $\begin{array}{l}0 \\
\text { ర్ } \\
\text { I }\end{array}$ & Eే & 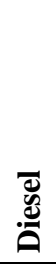 & 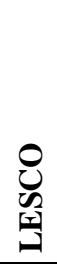 & 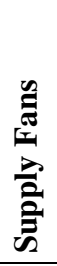 & 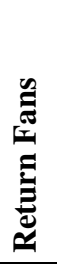 & 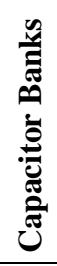 & 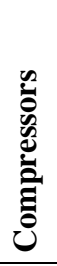 & 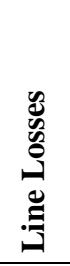 & 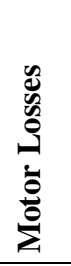 & 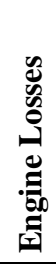 & 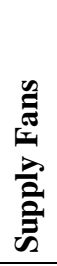 & 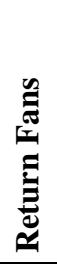 & 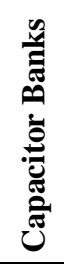 & 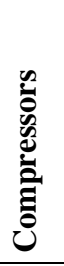 & 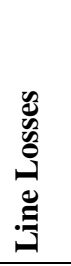 & 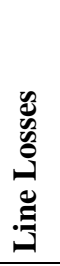 & 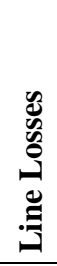 \\
\hline $\bar{\Xi}$ & 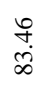 & $\stackrel{\oplus}{\stackrel{9}{2}}$ & $\overrightarrow{\vec{A}}$ & $\stackrel{\text { fे }}{r}$ & $\begin{array}{l}\stackrel{0}{m} \\
\stackrel{m}{n}\end{array}$ & $\begin{array}{l}\stackrel{\circ}{n} \\
\stackrel{m}{n}\end{array}$ & $\begin{array}{l}\overline{\mathbf{D}} \\
\text { do }\end{array}$ & 总 & 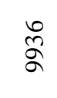 & $\begin{array}{l}\stackrel{8}{\infty} \\
\stackrel{\infty}{\circ}\end{array}$ & $\underset{⿱}{\stackrel{2}{8}}$ & 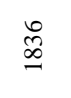 & $\stackrel{m}{\vec{n}}$ & 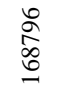 & \begin{tabular}{l}
$\infty$ \\
$\stackrel{\circ}{\circ}$ \\
\multirow{0}{0}{}
\end{tabular} & $\underset{\substack{\hat{n} \\
\text { m }}}{m}$ & $\begin{array}{l}\infty \\
\infty \\
\infty \\
\infty \\
\infty\end{array}$ & 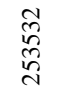 & $\frac{\circ}{0}$ & $\underset{⿱}{\stackrel{+}{*}}$ \\
\hline$\vec{z}$ & $\frac{\hat{\sigma}}{\sigma}$ & $\stackrel{m}{0}$ & $\stackrel{?}{\stackrel{2}{r}}$ & $\stackrel{\infty}{m}$ & $\stackrel{R}{\stackrel{R}{g}}$ & m. & $\begin{array}{l}\bar{a} \\
\text { do }\end{array}$ & 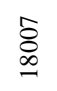 & 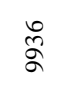 & $\begin{array}{l}\stackrel{\&}{\&} \\
\stackrel{\circ}{\circ}\end{array}$ & $\stackrel{\frac{N}{8}}{2}$ & $\underset{\infty}{\infty}$ & त्र & $\begin{array}{l}\overrightarrow{\mathbb{N}} \\
\stackrel{0}{0}\end{array}$ & $\stackrel{5}{\frac{5}{0}}$ & ల్య & 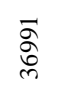 & 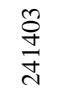 & $\begin{array}{l}\infty \\
\stackrel{\infty}{0} \\
\mathbb{b}^{2}\end{array}$ & $\vec{ర}$ \\
\hline $\mathscr{\mathscr { ~ }}$ & 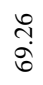 & $\stackrel{8}{\circ}$ & $\begin{array}{l}\text { ț } \\
\text { 官 }\end{array}$ & $\underset{m}{m}$ & $\stackrel{8}{\circ}$ & $\underset{\sim}{\tilde{r}}$ & $\begin{array}{l}\bar{\Xi} \\
\text { d. }\end{array}$ & $\begin{array}{l}\hat{\delta} \\
\stackrel{\infty}{\infty}\end{array}$ & రి & $\begin{array}{l}\stackrel{8}{\infty} \\
\stackrel{0}{\circ}\end{array}$ & $\underset{⿱}{\stackrel{2}{8}}$ & $\underset{\infty}{\infty}$ & 곡 & $\begin{array}{c}\underset{\omega}{\omega} \\
\stackrel{\sigma}{0}\end{array}$ & $\frac{9}{\sigma}$ & 㱟 & $\underset{n}{\stackrel{n}{n}}$ & 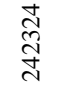 & $\stackrel{0}{3}$ & $\underset{\infty}{\mathbb{d}}$ \\
\hline สี & $\begin{array}{l}\text { s. } \\
\text { i. }\end{array}$ & तु & $\begin{array}{l}\stackrel{P}{0} \\
\dot{\infty} 0\end{array}$ & $\stackrel{m}{m}$ & 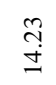 & $\begin{array}{l}\infty \\
\infty \\
\infty \\
\infty\end{array}$ & $\begin{array}{l}\bar{\alpha} \\
\text { do }\end{array}$ & $\begin{array}{l}\hat{\delta} \\
\stackrel{\infty}{\infty}\end{array}$ & ס̊ & $\begin{array}{l}\stackrel{8}{\circ} \\
\stackrel{\circ}{9}\end{array}$ & $\underset{⿱}{\stackrel{2}{2}}$ & $\underset{\infty}{\infty}$ & $\frac{m}{2}$ & $\begin{array}{l}\bar{\sigma} \\
\text { बे }\end{array}$ & 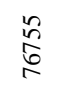 & 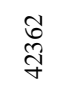 & $\begin{array}{l}\text { 竎 } \\
\text { o }\end{array}$ & 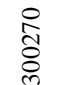 & $\underset{\substack{\infty \\
\infty}}{\infty}$ & $\overrightarrow{\mathbf{s}}$ \\
\hline$\stackrel{\square}{ \pm}$ & $\begin{array}{l}\infty \\
\dot{\infty} \\
\infty\end{array}$ & $\stackrel{8}{i}$ & @্ & $\underset{r}{\mathbb{r}}$ & $\begin{array}{l}\bar{n} \\
\stackrel{I}{I}\end{array}$ & $\stackrel{\infty}{\stackrel{\infty}{m}^{2}}$ & $\begin{array}{l}\bar{\Xi} \\
\text { d }\end{array}$ & $\begin{array}{l}\hat{\delta} \\
\stackrel{\infty}{\infty}\end{array}$ & $\begin{array}{l}0 \\
\text { న̊ }\end{array}$ & $\begin{array}{l}\stackrel{8}{\circ} \\
\stackrel{\circ}{9}\end{array}$ & $\underset{⿱}{\stackrel{2}{2}}$ & $\underset{\infty}{\infty}$ & $\stackrel{m}{n}$ & $\begin{array}{l}\underset{J}{J} \\
\stackrel{J}{I}\end{array}$ & 웅 & $\begin{array}{l}\text { D. } \\
\text { ర్లి }\end{array}$ & $\frac{\infty}{\stackrel{+}{\sigma}}$ & 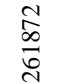 & $\begin{array}{l}\text { वे } \\
\infty \\
0\end{array}$ & $\vec{\sigma}$ \\
\hline$\stackrel{\tilde{w}}{\Sigma}$ & $\stackrel{\infty}{\stackrel{\infty}{\sigma}}$ & $\stackrel{5}{0}$ & 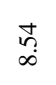 & $\stackrel{f}{f}$ & $\stackrel{\sigma}{\circ}$ & $\stackrel{\infty}{n}$ & $\begin{array}{l}\bar{\alpha} \\
\text { do }\end{array}$ & $\begin{array}{l}\hat{\text { ô }} \\
\text { }\end{array}$ & চి & $\begin{array}{l}\stackrel{8}{\circ} \\
\stackrel{\infty}{9}\end{array}$ & $\stackrel{\text { 导 }}{2}$ & $\underset{\infty}{\infty}$ & $\frac{m}{\vec{n}}$ & 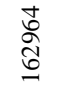 & $\begin{array}{l}\infty \\
\text { 心్ర } \\
\text { రె }\end{array}$ & 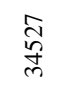 & స్ & 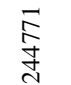 & 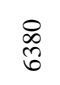 & $\vec{\infty}$ \\
\hline 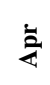 & $\stackrel{0}{\stackrel{0}{\infty}}$ & సิ & $\begin{array}{l}\infty \\
\stackrel{\infty}{\varrho}\end{array}$ & $\stackrel{\infty}{\text { r }}$ & 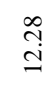 & $\stackrel{8}{\circ}$ & $\begin{array}{l}\bar{\vdots} \\
\text { ò }\end{array}$ & $\begin{array}{l}\hat{\delta} \\
\stackrel{\infty}{\infty}\end{array}$ & 条 & $\begin{array}{l}\stackrel{8}{\circ} \\
\stackrel{\infty}{\subseteq}\end{array}$ & $\underset{⿱}{\stackrel{2}{2}}$ & 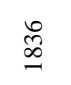 & $\stackrel{m}{\vec{d}}$ & $\begin{array}{l}\text { ò } \\
\text { ô }\end{array}$ & $\frac{\Delta}{\mathrm{m}}$ & $\begin{array}{l}\text { dे } \\
\text { dे }\end{array}$ & 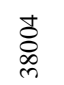 & $\begin{array}{l}0 \\
\stackrel{0}{0} \\
\stackrel{0}{J}\end{array}$ & $\begin{array}{l}\overline{0} \\
\text { ơ }\end{array}$ & 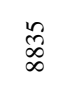 \\
\hline$\stackrel{m}{\Sigma}$ & 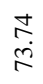 & ֻั & 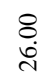 & 芦 & 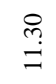 & $\begin{array}{l}\vec{\infty} \\
i\end{array}$ & $\begin{array}{l}\bar{\Xi} \\
\text { ò }\end{array}$ & 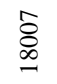 & ๙ু & $\begin{array}{l}\mathbb{8} \\
\stackrel{\infty}{9}\end{array}$ & $\underset{⿱}{\stackrel{f}{*}}$ & $\underset{\infty}{\infty}$ & $\stackrel{m}{\vec{n}}$ & 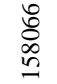 & $\begin{array}{l}\infty \\
0 \\
0 \\
0\end{array}$ & 常 & $\begin{array}{l}\infty \\
\infty \\
0 \\
ల ్ ల n\end{array}$ & $\underset{\substack{n\\
}}{\frac{n}{7}}$ & $\begin{array}{l}\infty \\
\infty \\
0\end{array}$ & $\begin{array}{l}\text { ôt } \\
\text { do }\end{array}$ \\
\hline$\underline{\Xi}$ & 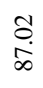 & సิ & $\begin{array}{l}\stackrel{a}{\mathrm{~d}} \\
\mathrm{~d}\end{array}$ & $\stackrel{\leftrightarrow}{\oplus}$ & $\underset{\infty}{\infty}$ & $\stackrel{8}{8}$ & $\begin{array}{l}\bar{\sigma} \\
\text { òd }\end{array}$ & 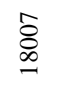 & হి & $\begin{array}{l}8 \\
\stackrel{8}{9} \\
\stackrel{0}{9}\end{array}$ & 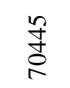 & 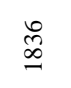 & $\underset{n}{n}$ & 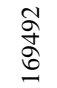 & \begin{tabular}{l}
$n$ \\
\multirow{2}{*}{} \\
6
\end{tabular} & 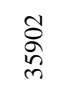 & $\begin{array}{l}\text { స్ } \\
\text { ळे } \\
\text { ले }\end{array}$ & $\begin{array}{l}\text { o } \\
\text { is } \\
\text { wi }\end{array}$ & $\begin{array}{l}\text { t艹 } \\
\text { d. }\end{array}$ & $\vec{\alpha}$ \\
\hline$\Xi$ & $\stackrel{\sigma}{\approx}$ & $\stackrel{?}{f}$ & $\begin{array}{l}\text { : } \\
\text { à }\end{array}$ & $\underset{\sim}{\sigma}$ & $\stackrel{m}{\stackrel{?}{I}}$ & 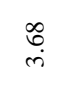 & $\begin{array}{l}\bar{\alpha} \\
\text { do }\end{array}$ & $\begin{array}{l}\hat{\text { ô }} \\
\text { }\end{array}$ & 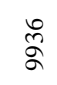 & $\begin{array}{l}\stackrel{8}{\circ} \\
\stackrel{\circ}{=}\end{array}$ & $\underset{⿱}{\stackrel{q}{*}}$ & $\underset{\infty}{\infty}$ & $\stackrel{m}{a}$ & 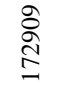 & $\begin{array}{l}\bar{\infty} \\
\widehat{0} \\
0\end{array}$ & 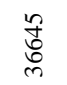 & $\begin{array}{l}\vec{m} \\
\text { D. }\end{array}$ & 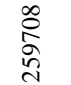 & $\underset{\hat{6}}{\mathbb{8}}$ & 总 \\
\hline$\frac{20}{2}$ & $\begin{array}{c}\text { के } \\
\infty \\
\infty\end{array}$ & $\stackrel{:}{\circ}$ & $\stackrel{\bar{\sigma}}{\exists}$ & $\underset{\sim}{+}$ & $\vec{m}$ & $\underset{\sigma}{\tilde{r}}$ & $\begin{array}{l}\bar{\delta} \\
\text { òd }\end{array}$ & $\begin{array}{l}\hat{0} \\
\stackrel{\infty}{\infty}\end{array}$ & ๙ু & $\begin{array}{l}\stackrel{8}{\circ} \\
\stackrel{\infty}{\circ}\end{array}$ & $\underset{\&}{\stackrel{f}{\&}}$ & $\stackrel{\infty}{\infty}$ & 党 & 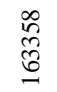 & ત્તิ & $\begin{array}{l}\text { o } \\
\text { ơ } \\
\text { 我 }\end{array}$ & $\underset{\infty}{\frac{1}{n}}$ & 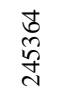 & ڤ్ & $\underset{\substack{n \\
\infty}}{N}$ \\
\hline \multirow[t]{2}{*}{ ஜัँ } & $\begin{array}{l}\infty \\
\stackrel{\infty}{a} \\
\vdots\end{array}$ & $=$ & $\begin{array}{l}\bar{\infty} \\
i\end{array}$ & $\tilde{ల}_{\vec{r}}$ & 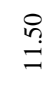 & in & $\begin{array}{l}\bar{\Delta} \\
\text { d̆ㅇ }\end{array}$ & 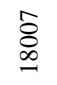 & ס̊ & 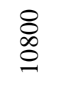 & $\underset{⿱}{\stackrel{f}{+}}$ & $\underset{\infty}{\infty}$ & 芳 & 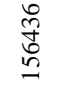 & 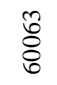 & $\frac{\infty}{d}$ & 庆 & 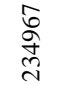 & $\frac{\pi}{0}$ & $\begin{array}{c}\bar{\infty} \\
\infty \\
\infty\end{array}$ \\
\hline & & & & & & & & & & & & & & 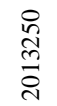 & $\underset{\stackrel{N}{N}}{\stackrel{N}{N}}$ & \begin{tabular}{l} 
ơ \\
\multirow{0}{0}{} \\
ఫे
\end{tabular} & 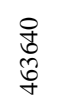 & $\begin{array}{l}\text { ô } \\
\text { ஸे } \\
\text { ర్లి }\end{array}$ & $\begin{array}{l}\stackrel{\circ}{\infty} \\
\stackrel{\infty}{\infty}\end{array}$ & 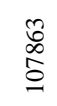 \\
\hline
\end{tabular}




\section{CONCLUSIONS}

Based on the detailed energy audit, it is observed that the highest cost of energy was observed of LESCO; hence gas is recommended to be used. An average annual efficiency of $33.3,34.1,33.9$, and $34.3 \%$ is calculated for gas engines 1, 2, 3, and 4 respectively; hence, engine 4 is recommended to be used more and engine 1 the least. Regarding load distribution, maximum consumption is observed in the months of February and March. Maximum energy consumption is observed in the spinning units $1 \& 2$. Total energy loss per month from motors, capacitors, compressors is calculated as $10,074 \mathrm{kWh}, 1,836 \mathrm{kWh}$ and $10,800 \mathrm{kWh}$ respectively. Power saving of 570,626 kWh from supply fans and 219,088kWh from return fans is observed.

\section{ACKNOWLEDGEMENT}

Author acknowledges the support of Hira Textile Mills Limited Lahore, Pakistan for their full support and help in completing this study.

\section{REFERENCES}

[1] Pradeep C. (1996) Sustainable energy supply in Asia. Proceedings of the International Conference, Asia Energy Vision 2020, November 15-17, 1996. Concept Publishing Company, India.

[2] Albert T. (1989) Plant engineers and managers guide to energy conservation, $4^{\text {th }}$ edn. Fairmont Publishing.

[3] Hartungi R, Jiang L. (2012) Energy efficiency and conservation in an office building: A case Study. Intl. J. of Energy Sector Management. 6(2):175-188.

[4] McMullan JT, Morgan R. (2007) A device for recording electrical information. Intl. J. of Energy Res., 4(1):11-17.

[5] Balasubramanian P. (2004) Energy auditing made simple. Bala Consultancy Services, Mylapore, India.

[6] Chanda RS. (2014) On energy auditing: An experience with a jute mill. Intl. J. on Recent Innov. Trends Comp. Comm., 2(10):3134-3137.

[7] Chase J, Lucas NJD, Murgatroyd W, Wilkins BC. (2007) Industrial energy use-II: Energy use in a light engineering factory. Intl. J. of Energy Res., 2(4):375-388.

[8] Jouni K, Iikka S. (2001) Cleaner energy production in industrial recycling networks. EcoManagement and Auditing, 8(2):144-153.

[9] Virginia WJ, William SJ, Joann CJ. (2007) Impact of energy audits on home energy consumption. Intl. J. of Consumer Studies, 11(1):21-38.

[10] Paul OC. (1993) Energy management. McGraw-Hill Professional Publishing.

[11] Tyagi AK. (2000) Handbook on energy audits and management. TERI, India.

[12] Earle AP. (1985) A case history: Energy conservation in the primary textile industry in Canada. National Technical Conference of AATCC, pp. 215.

[13] Dhayaneswaran Y, Ashokkumar L. (2013) A study on energy conservation in textile industry. J. Inst. Eng. India Ser. B. 94(1):53-60. Doi: 10.1007/s40031-013-0040-5.

[14] Palanichamy C, Nadarajan C, Naveen P, Babu NS, Dhanalakshmi. (2001) Budget constrained energy conservation - An experience with a textile industry. IEEE Trans. Energy Conversion, 16(4):340-345.

[15] Prakasam R, Chandran KR. (2013) SITRA energy audits for textile mills. Textile Magazine, 44(8): p 69.

[16] Hasanbeigi A, Hasanabadi A, Abdorrazaghi M. (2011) Energy efficiency technologies and comparing the energy intensity in the textile industry. ACEEE Summer Study on Energy Efficiency in Industry, 1:34-46. 
[17] Şekkeli M, Keçecioğlu OF. (2012) SCADA based energy saving approach to operation of stenter machine in a textile plant using waste heat recovery system. Journal of Textile \& Apparel / Tekstil ve Konfeksiyon, 22(3):248-257.

[18] Masood A K, Muhammad S, Iftikhar S, Altaf H, Wasi U, Shabbir F. (2015) Energy efficiency in textile sector of Pakistan: Analysis of energy consumption of air-conditioning unit. Intl. J. of Env. Sci. Dev., 6(7): 1-11.

[19] http://www.ems-textile.net

[20] http://www.ptj.com.pk

[21] http://textilemagazine.awardspace.com 